\title{
Parasite prevalence in blue-eyed black lemurs Eulemur flavifrons in differently degraded forest fragments
}

\author{
Nora Schwitzer ${ }^{1,4}$, Dagmar Clough ${ }^{2}$, Horst Zahner ${ }^{1}$, Werner Kaumanns ${ }^{3}$, \\ Peter Kappeler ${ }^{2}$, Christoph Schwitzer ${ }^{4, *}$ \\ ${ }^{1}$ Institut für Parasitologie, Justus-Liebig-Universität, Rudolf-Buchheim-Strasse 2, 35392 Giessen, Germany \\ ${ }^{2}$ Abteilung Verhaltensökologie \& Soziobiologie/Anthropologie, Deutsches Primatenzentrum, Kellnerweg 4, \\ 37077 Göttingen, Germany \\ ${ }^{3}$ Eschenweg 5, 37130 Gleichen, Germany \\ ${ }^{4}$ Bristol Conservation and Science Foundation, Bristol Zoo Gardens, Clifton, Bristol BS8 3HA, UK
}

\begin{abstract}
The parasite burden of an animal population has frequently been used as an indicator of the stress level to which the population is exposed. Primates inhabiting small forest fragments are more likely to experience human contact, reduced food availability and restricted ranging - any or all of which may contribute to a higher parasite prevalence - than populations inhabiting intact primary forest. Recent and ongoing human exploitation of otherwise intact forest may also affect disease burden and parasite transmission in primates. The parasites of blue-eyed black lemurs Eulemur flavifrons have not as yet been subject to scientific research. This paper describes the various parasites found in E. flavifrons and shows parasite prevalence in lemur groups living in differently degraded fragments of the Ankarafa Forest in Sahamalaza National Park, northwest Madagascar. We analysed 166 faecal samples of E. flavifrons inhabiting primary forest and 168 from groups inhabiting secondary forest. In addition, faecal samples and ectoparasites were collected from 18 immobilised lemurs. Forty-three (12.9\%) samples contained parasite eggs (Lemuricola spp. and Callistoura spp.) or oocysts. Ten (55.6\%) of the 18 samples from immobilised lemurs contained adult Lemuricola spp. Parasite prevalence was significantly higher in secondary than in primary forest, at 7.9 and $4.8 \%$ of all positive samples, respectively. Prevalence was high when compared to other studies on parasite load in wild lemurs, suggesting that in our survey area, E. flavifrons were generally under pressure, possibly due to the high degree of fragmentation and degradation of the remaining forest habitat.
\end{abstract}

KEY WORDS: Eulemur flavifrons - Primary forest - Secondary forest $\cdot$ Lemuricola $\cdot$ Callistoura Seasonality

Resale or republication not permitted without written consent of the publisher

\section{INTRODUCTION}

Health and disease issues have been recognised as important factors in wildlife management for many years (Dobson 1988, May et al. 1988, Thorne et al. 1988, Spalding \& Forrester 1993). Various scientists have investigated the impact of diseases and their prevention as a factor in conserving wildlife (Nizeyi et al. 1999, 2002a,b, Daszak et al. 2000, Graczyk et al. 2001). Parasites and infectious diseases can influence popula- tion dynamics of their hosts in various ways (Taraschewski 2006). For instance, Gillespie \& Chapman (2004) suggested that parasitic diseases played a role in the population decline of Procolobus badius and Colobus guereza living in forest fragments in Kibale National Park, Uganda, and in forest fragments to the west of the park surrounded by an agricultural landscape. When small populations are fragmented into remnant islands, the effects of diseases may be more pronounced (Foose 1991). Schad et al. (2005) found a 
higher parasite load in mouse lemurs Microcebus murinus living in the second-smallest of 4 studied forest fragments. The high parasite prevalence was associated with lower genetic diversity and with a high frequency of a particular allele of the major histocompatibility complex that was found significantly more often in infected than in parasite-free individuals.

In order to assess and manage the effect of parasites on population dynamics, it is essential to evaluate their incidence and prevalence in wild populations (Karesh \& Cook 1995, Mörner 2002, Williams et al. 2002, Junge \& Louis 2005a,b). Longitudinal surveying of primate faeces for intestinal parasites provides a valuable resource for the study of ecological relationships between primates and their environment (Hahn et al. 2003). Changes in patterns of gastro-intestinal parasites may reflect differences in parasitic transmission, host dietary preferences and habitat utilisation (Stuart et al. 1998).

Until relatively recently, only a handful of studies on lemur parasites had been published (Huff \& Hoogstraal 1962, Chabaud et al. 1965, Garnham \& Uilenberg 1975, Rabetafika et al. 1989, Hugot et al. 1995). In their comprehensive review paper, Chabaud et al. (1965) reported several parasites in Eulemur albifrons and E. fulvus: Callistoura blanci, Lemuricola vauceli, $L$. baltazardi and L. bauchoti. They also described 1 parasite species each in Microcebus murinus and Cheirogaleus medius, and gave an overview of the parasites of Cheirogaleus major, Cheirogaleus medius, Lepilemur mustelinus, Lepilemur ruficaudatus, Varecia variegata, Eulemur macaco, Eulemur rufus, Eulemur mongoz, Hapalemur sp., Hapalemur griseus, Indri indri, Propithecus verreauxi, Propithecus coquereli, Avahi occidentalis and Daubentonia madagascariensis from samples taken from captive lemurs at Parc Botanique et Zoologique de Tsimbazaza, Antananarivo, Madagascar. In the following $30 \mathrm{yr}$, only few lemur parasites were added to the list of known species. More recently, however, several researchers began focussing on, or at least including, parasites of lemurs in their studies. Within the scope of biomedical evaluations of wild lemur populations, sporadically appearing nematodes of various sorts as well as mites were described in different lemur species (Junge \& Louis 2005a for Varecia variegata and Varecia rubra; Junge \& Louis 2005b for Propithecus verreauxi deckeni and Eulemur fulvus rufus; Junge \& Louis 2007 for Eulemur macaco; Junge et al. 2008 for Eulemur albifrons; Dutton et al. 2003 for Lemur catta, Dutton et al. 2008 for Varecia rubra). Junge \& Louis (2005a) also reported an infestation of ticks Haemophysalis lemuris in Varecia spp. An overview of endo- and ectoparasites found in various wild lemurs was provided by Junge \& Sauther (2006). Raharivololona \& Ganzhorn $(2009,2010)$ re- corded 9 gastrointestinal parasite species in faecal samples of wild Microcebus murinus. In describing the parasites of blue-eyed black lemurs Eulemur flavifrons and investigating parasite prevalence in Eulemur flavifrons groups living in differently degraded fragments, our study adds to the growing number of papers focussing on parasites in wild lemur populations.

The blue-eyed black lemur Eulemur flavifrons, the taxonomic validity of which was confirmed independently by Rabarivola (1998) and Pastorini (2000), was rediscovered by science only in 1983, after more than a century of uncertainty about its existence (Koenders et al. 1985, Meier et al. 1996). Mittermeier et al. (2008) elevated the taxon (a former subspecies of E. macaco) to full species status, based on the consistency of the morphological differences between black lemurs and blue-eyed black lemurs as well as on the fact that the hybridisation zone between the 2 taxa seemed to be smaller than previously thought. We follow their taxonomy in this paper. E. flavifrons is still one of the least studied of all Eulemur species. It occurs exclusively in northwestern Madagascar in a very small area of about $2700 \mathrm{~km}^{2}$ south of the Andranomalaza, north of the Maevarano, and west of the Sandrakota rivers, where it inhabits primary and secondary forest fragments (Koenders et al. 1985, Meyers et al. 1989, Rabarivola et al. 1991, Mittermeier et al. 1994). The species' repartition area lies within a transition zone between the humid Sambirano region in the north and the western dry deciduous forest region in the south. The repartition area harbours semi-humid forests with tree heights of up to $30 \mathrm{~m}$ on ferruginous alkalescent and alkaline soils based on sandstone, basalt or clay (IRNT 1991a).

Only a small total population of Eulemur flavifrons remains, the largest part of which lives in forest fragments on and adjacent to the Sahamalaza Peninsula of Madagascar (Mouton 1999, Schwitzer et al. 2005, 2006). E. flavifrons was assessed as Critically Endangered (CR A2cd) by the International Union for the Conservation of Nature (IUCN) at their most recent Red List Assessment in April 2005, based on an $80 \%$ population reduction during the last $25 \mathrm{yr}$. The principal threats to its survival are forest destruction due to slash-and-burn agriculture and selective logging, continued hunting and trapping (Schwitzer et al. 2006).

This paper describes parasite prevalence in blueeyed black lemurs living in differently degraded forest fragments. Our aims were to describe the various parasites found in Eulemur flavifrons, and to determine possible differences in parasite burden of the lemurs between primary and secondary forest in order to begin evaluating the suitability of degraded habitats for the species. Based on studies of parasite prevalence among other primate species living in forest fragments 
(Gillespie \& Chapman 2004, Schad et al. 2005), we predicted that blue-eyed black lemurs in secondary, more degraded forest would show a higher parasite burden than groups in primary forest. Taking into account the severe fragmentation of the remaining forest habitat in Sahamalaza, we also predicted that parasite prevalence would be high in E. flavifrons as compared to other species of Eulemur.

\section{MATERIALS AND METHODS}

Study site. The study was conducted in the Ankarafa Forest, situated within the National Park and UN Biosphere Reserve on the Sahamalaza Peninsula, which is part of the Province Autonome de Mahajanga, NW Madagascar, and extends between $13^{\circ} 52^{\prime}$ and $14^{\circ} 27^{\prime} \mathrm{S}$ and $45^{\circ} 38^{\prime}$ and $47^{\circ} 46^{\prime} \mathrm{E}$ (WCS/DEC 2002; Fig. 1). The Ankarafa Forest includes primary and secondary forest fragments which accommodate one of the presumably largest connected populations of blueeyed black lemurs (Schwitzer et al. 2005, 2006).

The climate is strongly seasonal, with a cool, dry season from May to October and a hot, rainy season from November to April (Schwitzer et al. 2007a,b). Mean annual precipitation is $1600 \mathrm{~mm}$ (IRNT 1991b), with the strongest rainfalls occurring in January and
February. Maximum average temperature is $32.0^{\circ} \mathrm{C}$ (November) and minimum average temperature is $20.6^{\circ} \mathrm{C}$ (August) (Schwitzer et al. 2007a,b).

Collections. We collected pooled faecal samples from 2 groups of Eulemur flavifrons per forest fragment, from 2 differently degraded fragments of the Ankarafa Forest during a 10 mo period between July 2004 and July 2005. Mean group size was 6 individuals and did not differ between forest fragments. The 2 fragments, one of which consisted mainly of primary, and the other of secondary vegetation, were linked to each other through an area covered by bushes and shrubs. Lemurs were never observed to cross between fragments. The secondary forest fragment was in the process of regeneration after significant human disturbance of the original forest vegetation over an extended period in the past. It displayed major differences in forest structure and canopy species composition to the nearby primary forest: median diameter at breast height $(\mathrm{DBH})$ of trees and the number of trees with lianas were significantly lower, as was the number of different plant families. All conditions for the definition of secondary forest given by Chokkalingam \& de Jong (2001) were met by this fragment. The 2 fragments also differed considerably with regard to their plant communities (for a detailed description of fragments, see Schwitzer et al. 2007a).

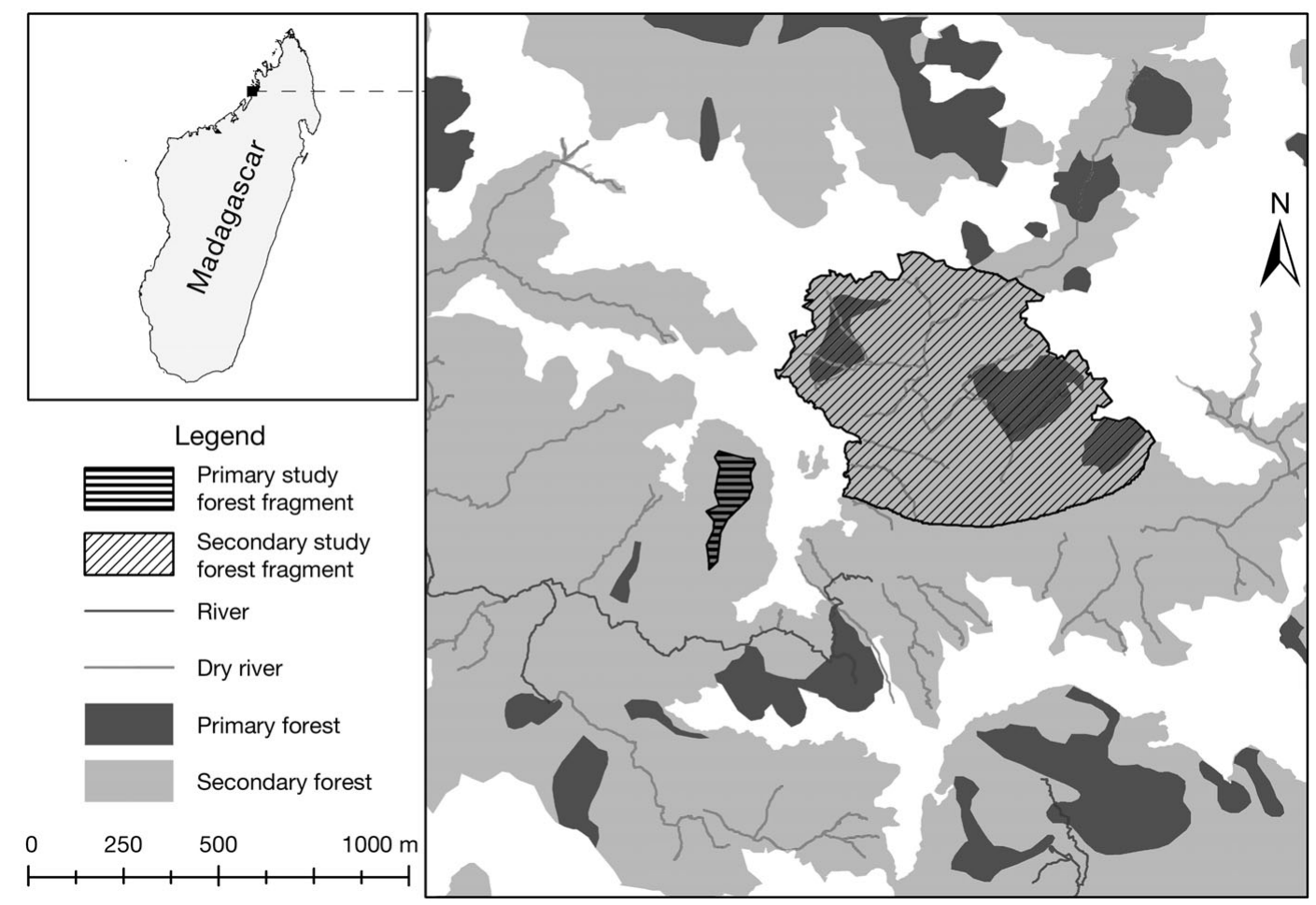

Fig. 1. Study site (fragments of the Ankarafa Forest) within the Sahamalaza-Iles Radama National Park. Non-shaded areas: grass savannah with shrubs. Map produced by Jamie Smith and James Thorn, adapted by Andrew Arnell 
As several individuals often defecated simultaneously and in close proximity to each other, the assignment of individual samples was ambiguous. We therefore pooled samples for each habitat on a daily basis. Using this method, we collected a total of 334 pooled samples, which included 166 samples from primary and 168 samples from secondary forest. Seventy of the samples were collected in the cool, dry (39 in primary and 31 in secondary forest) and 264 in the hot, rainy season (127 in primary and 137 in secondary forest), respectively. All faecal samples were taken at the latest 15 min after the animals had defecated.

The pooled samples were mixed thoroughly, and 2 subsamples of $1.0 \mathrm{~g}$ each were taken and covered with sodium acetate, acetic acid, formalin (SAF) solution. For the SAF solution, $15 \mathrm{~g}$ of sodium acetate were mixed with $20 \mathrm{ml}$ of acetic acid (98\%), $40 \mathrm{ml}$ of formalin (40\%) and $925 \mathrm{ml}$ of distilled water (Mehlhorn et al. 1995).

Faecal samples and ectoparasites were also collected from 18 immobilised blue-eyed black lemurs living in the secondary forest fragment between May 2004 and October 2004; these samples were stored in $70 \%$ ethanol.

Faecal sample analysis. We examined all faecal samples for parasite ova using the SAF enrichment method (Ash \& Orihel 1987). Samples were shaken up and poured through a gauze filter into a test tube. They were then centrifuged for $2 \mathrm{~min}$ at $3000 \mathrm{rpm}$ and the supernatant was discarded. We added $7 \mathrm{ml}$ of $\mathrm{NaCl}$ solution and 2 to $3 \mathrm{ml}$ of ether, mixed it with the sediment and centrifuged again for $2 \mathrm{~min}$ at $3000 \mathrm{rpm}$. The supernatant was discarded and the sediment analysed under a microscope.

A finding of parasite ova or larvae in at least 1 of the 2 subsamples for a given day and habitat resulted in a positive report of that parasite for the respective data.

The faecal samples taken from the immobilised lemurs were studied under a light microscope (magnification: $100 \times$ ) as temporary wet mounts, first in water and later in lactophenol (Hugot et al. 1995). Using a measuring eyepiece we measured male and female body length, width, and lengths of pharynx, oesophagus and bulbus in all detected adult parasites, and length and width of 3 eggs per parasite species, and 3 oocysts.

Ectoparasite analysis. Ectoparasites were embedded in a Berlese mixture (Krantz 1978). For the latter, 20 units of glycerine were mixed with 50 units of distilled water; 200 units of chloral hydrate and 30 units of arabic gum were dissolved in the solution. The mixture was then filtered and stored until it was clear. One drop of the Berlese mixture was dropped onto a slide, and the ectoparasites were adjusted in a ventral or dorsal position, covered and photographed.
Data analysis. An extension of Fisher's exact test to k-by-2 contingency tables was performed to determine possible differences in parasite prevalence between primary and secondary forest. For statistical analyses we used SsS 2.0 (www.zoolution.de).

\section{RESULTS}

We analysed 166 faecal samples of Eulemur flavifrons from primary, and 168 from secondary forest. Forty-three $(12.9 \%)$ of all 334 samples contained parasite eggs (Lemuricola sp. and Callistoura sp.) or oocysts. For identification of the parasites we followed Chabaud et al. (1965).

The 3 Callistoura sp. eggs measured 51 by $86 \mu \mathrm{m}$ (length $\times$ width), 55.38 by $96.92 \mu \mathrm{m}$ and 44.73 by $86.84 \mu \mathrm{m}$, respectively. Eggs were oblong, symmetrical, had a clearly visible shell and were unembryonated (Fig. 2). They possessed an operculum on one of the poles.

Lemuricola sp. eggs were thin-shelled and similar in shape and size. The 3 eggs were asymmetrical and measured 30 by $61 \mu \mathrm{m}$ (length $\times$ width), 27 by $55 \mu \mathrm{m}$ and 32 by $64 \mu \mathrm{m}$, respectively, and each contained an embryo (Fig. 3).

In addition to the faeces samples collected in the forest we also collected samples directly from 18 individual immobilised blue-eyed black lemurs. Ten of these were positive for parasites $(55.6 \%)$ and contained adult Lemuricola sp.

In most of its morphological characteristics, such as fore-end and oesophagus shape, as well as the shape of the tail in males, the Lemuricola species found in Eulemur flavifrons resembled $L$. baltazardi (Chabaud et al. 1965). Morphological features that differed between the 2 are listed in Table 1. The buccal aperature of adult male and female Lemuricola sp. found in this study was delimited by 4 lips. The cuticula was finely coiled (Fig. 4). Side wings were short and prominent. Males had a long, robust and conical-ending tail (Fig. 4).

The 3 oocysts measured 31 by $29 \mu \mathrm{m}, 34$ by $31 \mu \mathrm{m}$ and 29 by $27 \mu \mathrm{m}$, were round, thick-shelled and unsporulated. A thin-shelled oblong structure with a mean size of 32 by $40 \mu \mathrm{m}$ was also regarded as an oocyst (Fig. 5).

Mites (Acari) were present on 6 of 18 lemurs and were only found on the inner side of the ears. Due to the advanced decay of the samples upon arrival in the laboratory they could not be identified below subclass level. Infection intensity was relatively low, with up to 10 specimens per infected animal. Mite infestation was not associated with evidence of disease and no other ectoparasites could be found. We did not detect any zoonotic parasites in any of the sampled lemurs. 

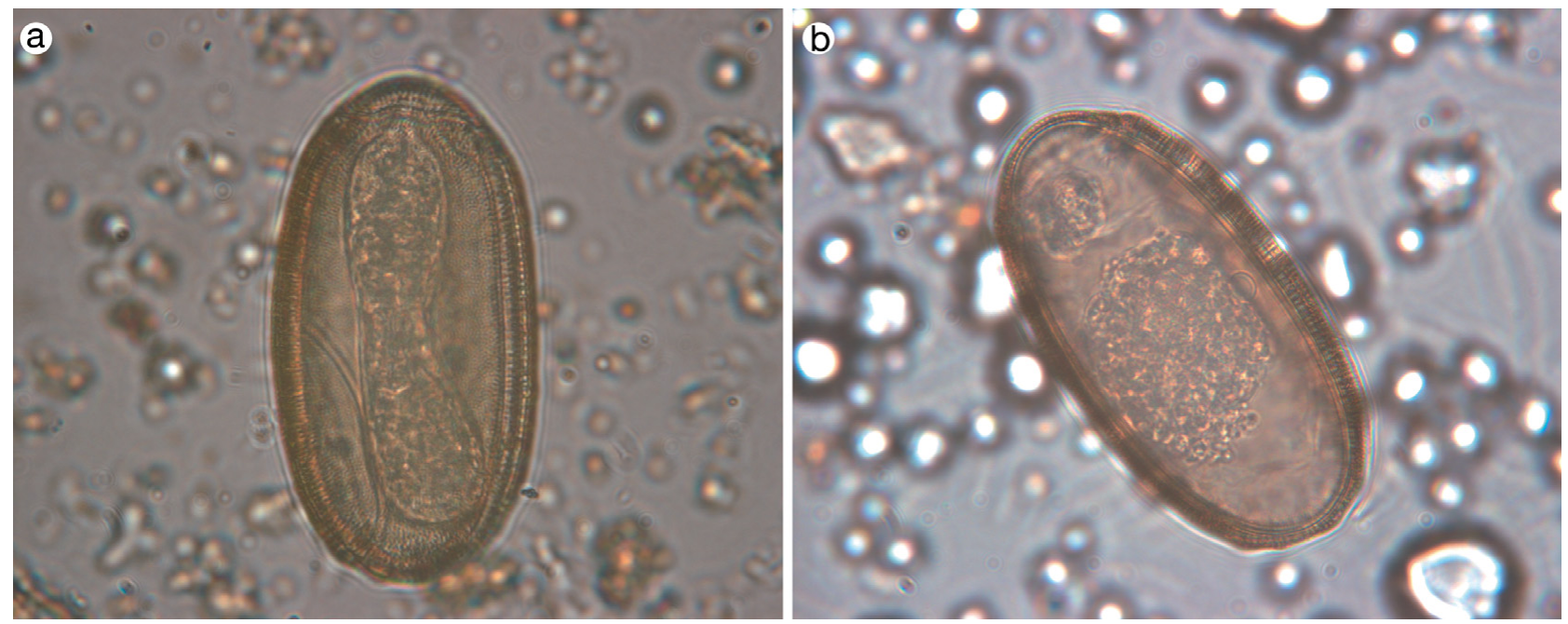

Fig. 2. Callistoura sp. egg at (a) 547× magnification and (b) 535× magnification
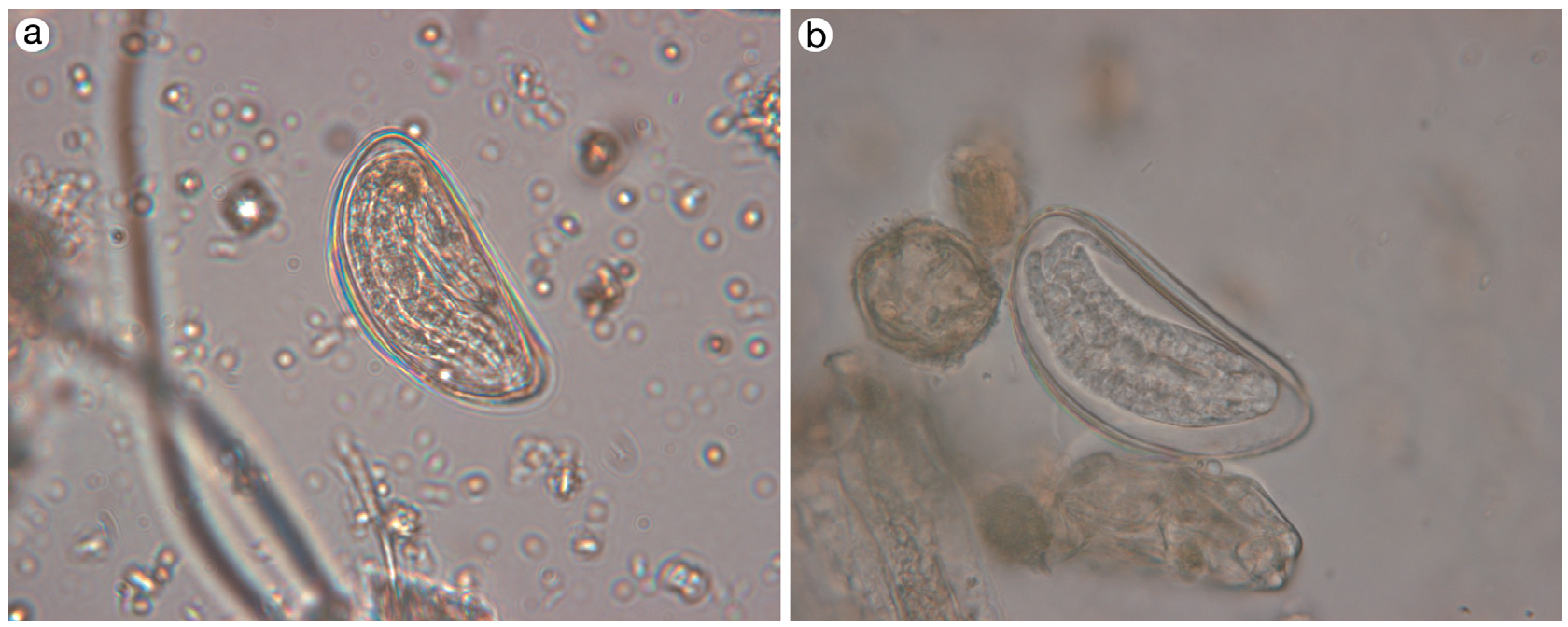

Fig. 3. Lemuricola sp. egg at (a) 459× magnification and (b) 541× magnification

Table 1. Lemuricola spp. Morphological differences between Lemuricola sp. found in the present study and L. baltazardi and $L$. vauceli. Measurements in $\mu \mathrm{m}$. Five specimens were measured for Lemuricola sp.; data for L. baltazardi and $L$. vauceli from Chabaud et al. (1965). pha: pharynx; oes: oesophagus

\begin{tabular}{|c|c|c|c|c|c|}
\hline \multirow{2}{*}{$\begin{array}{l}\text { Parameter } \\
(\mu \mathrm{m})\end{array}$} & \multicolumn{3}{|c|}{ Lemuricola sp. } & \multirow{2}{*}{$\begin{array}{c}\text { Lemuricola baltazardi } \\
\text { Mean }\end{array}$} & \multirow{2}{*}{$\begin{array}{c}\text { Lemuricola vauceli } \\
\text { Mean }\end{array}$} \\
\hline & Mean & Min. & Max. & & \\
\hline Body length male & 2712.5 & 2250 & 2812.5 & 3150 & 2800 \\
\hline Body length female & 4475 & 3625 & 4875 & 5300 & 5300 \\
\hline Width male & 298.8 & 248 & 375 & 220 & 200 \\
\hline Width female & 425 & 312 & 500 & 420 & 310 \\
\hline Length pha+oes male & 665.5 & 613 & 755 & 400 & 820 \\
\hline Length pha+oes female & 730 & 643 & 814 & 605 & 1290 \\
\hline Length bulbus male & 91.4 & 85 & 96 & 110 & 120 \\
\hline Length bulbus female & 105.2 & 96 & 121 & 125 & 150 \\
\hline Length pha+oes+bulbus male & 751.75 & 728 & 850 & 510 & 950 \\
\hline Length pha+oes+bulbus female & 835.2 & 735 & 910 & 730 & 1450 \\
\hline
\end{tabular}



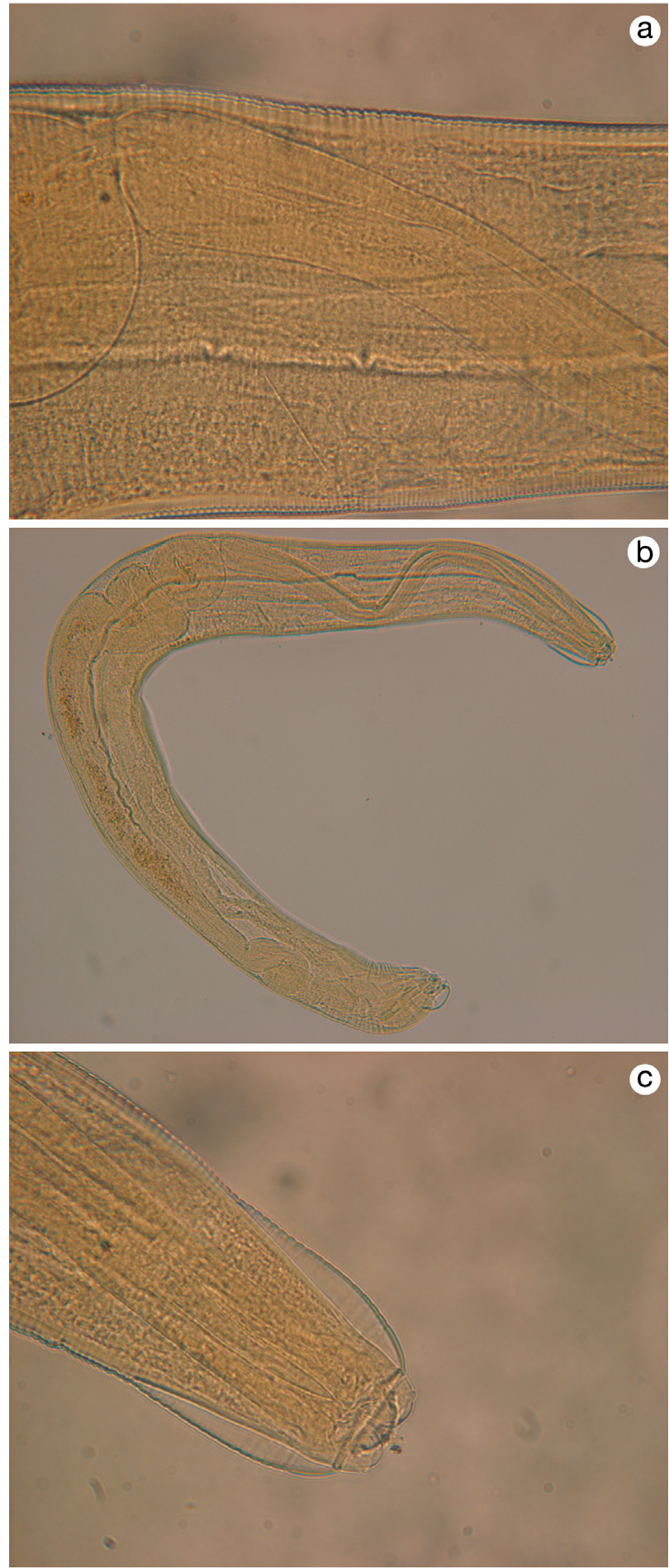

Fig. 4. Male Lemuricola sp. (a) at 1600× magnification. (b) Lemuricola sp. at $442 \times$ magnification. (c) Lemuricola sp. at $1700 \times$ magnification

The overall parasite expulsion was lower during the austral winter than during the austral summer, amounting to 4.2 and $8.7 \%$ of all positive samples,
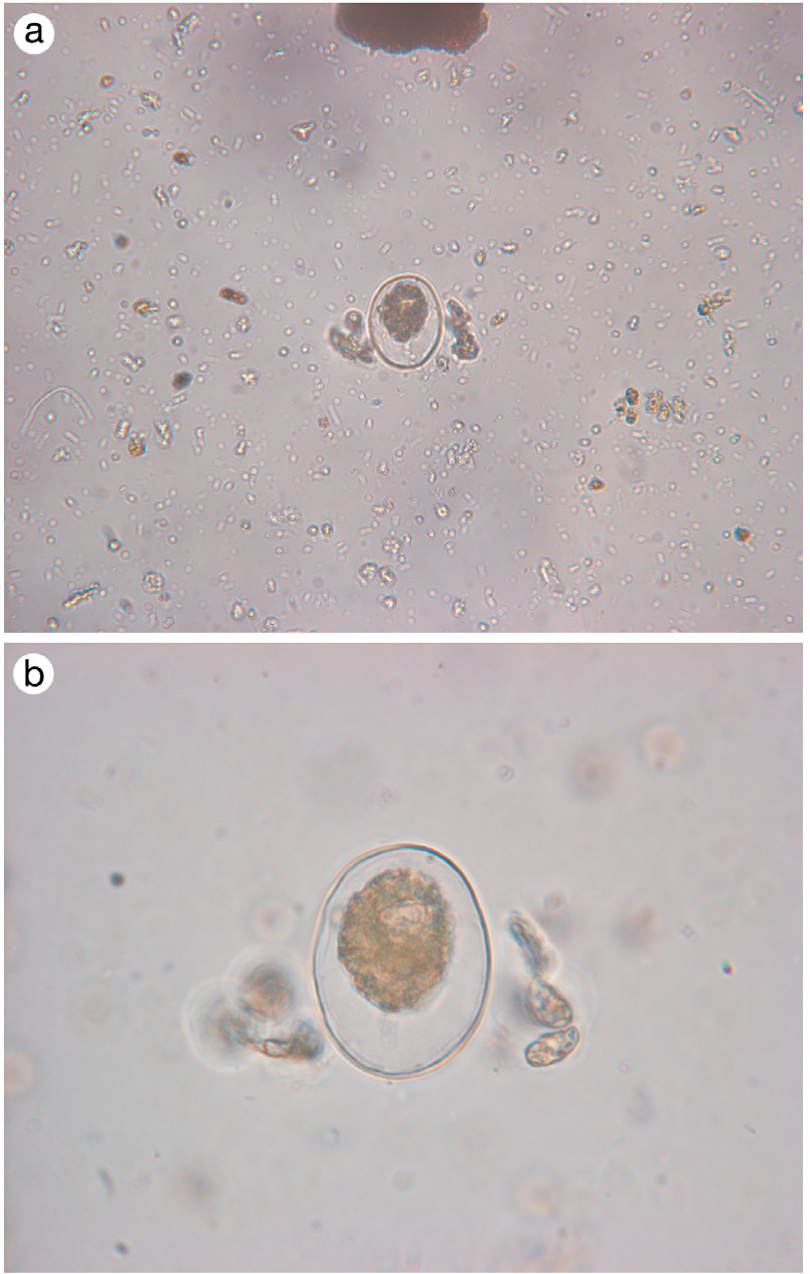

Fig. 5. Oocyst shown at (a) $212 \times$ and (b) $515 \times$ magnification

respectively. Parasite prevalence was significantly higher in secondary than in primary forest, with $4.8 \%$ of all positive samples found in primary and $7.9 \%$ in secondary forest (Extension Fisher test: $\mathrm{n}=334, \mathrm{p} \leq$ 0.05 ; Table 2). In all positive samples, eggs and larvae appeared only sporadically.

Table 2. Lemuricola sp. and Callistoura sp. Prevalence of nematode eggs and oocysts in Eulemur flavifrons faecal samples collected in primary and secondary forest (for statistics, see 'Results')

\begin{tabular}{|lcccc|}
\hline & \multicolumn{3}{c}{ Primary forest } \\
& $\begin{array}{c}\text { Positive } \\
\text { samples }\end{array}$ & \multicolumn{3}{c|}{$\begin{array}{c}\text { Secondary forest } \\
\text { Positive } \\
\text { samples }\end{array}$} \\
& & & \\
\hline Lemuricola sp. eggs & 7 & 2.1 & 8 & 2.4 \\
Callistoura sp. eggs & 7 & 2.1 & 7 & 2.1 \\
Oocysts & 2 & 0.6 & 10 & 2.99 \\
Total & 16 & 4.79 & 25 & 7.89 \\
\hline
\end{tabular}


Prevalence of eggs and oocysts varied over the year (Fig. 6). Egg and oocyst excretion by lemurs, independent of habitat type, was present during all months, except for April and June in primary, and December in secondary forest. Excretion by lemurs living in primary, forest never peaked above $20 \%$ of positive samples in any given month and was relatively evenly distributed over the year, with highest shedding in December, March and May. In secondary forest, egg and oocyst shedding was highest in the late rainy and the dry season, with a peak of $44.4 \%$ of positive samples in June.

In samples from primary forest, Callistoura sp. eggs were prevalent mainly during the rainy season, but with a peak of more than $14 \%$ of samples found positive in July (dry season). Some egg shedding also occurred in May. In secondary forest, a peak of more than $20 \%$ was found in June, and thus, in the dry season (Fig. 7).

Shedding of Lemuricola sp. eggs by lemurs living in primary forest habitat peaked in the dry season month of October, with $14.3 \%$ of samples found positive. Lemuricola sp. egg excretion by lemurs in secondary forest peaked in the dry season months of October, June and July (with up to $25 \%$ of samples found positive). Some shedding also occurred at the end of the rainy season (Fig. 8).

Oocysts were shed by lemurs, independent of their habitat, at the very beginning of the dry season and during the rainy season. In primary forest we found only 2 positive samples; these were excreted in March and December. In secondary forest we found more positive samples, the excretion of which peaked in April (Fig. 9).

\section{DISCUSSION}

Blue-eyed black lemurs were found to have intestinal parasites in both primary and secondary forest. Of all faecal samples collected, $12.9 \%$ from both forest types
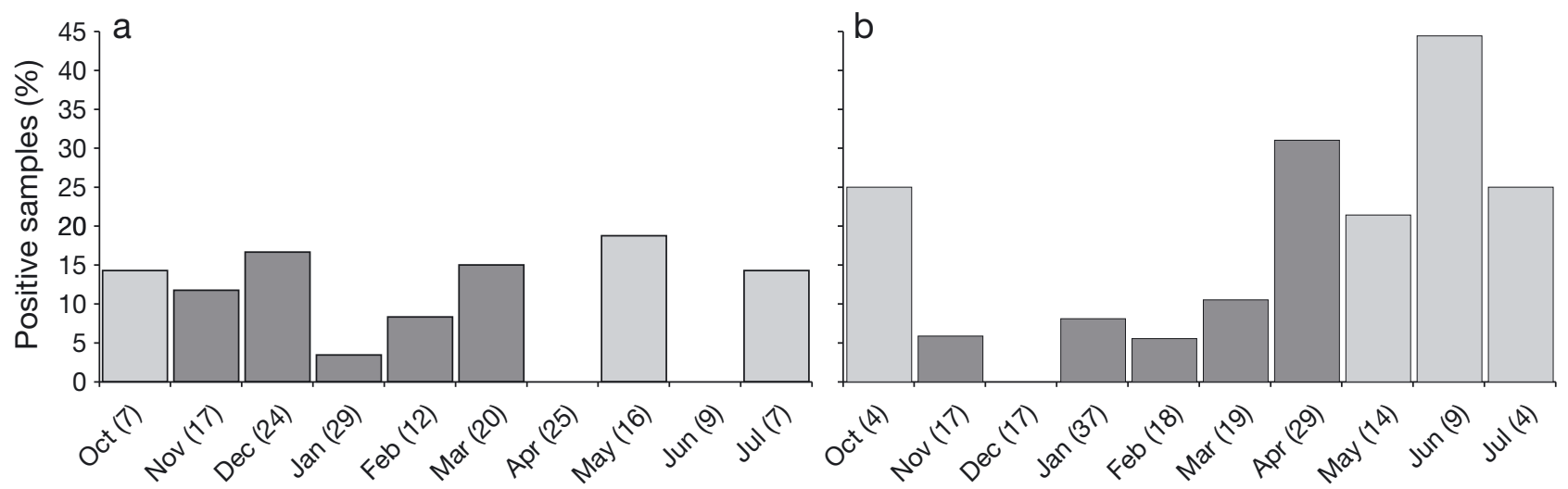

Fig. 6. Eulemur flavifrons. Total parasite egg and oocyst excretion in (a) primary and (b) secondary forest over the study period. Light bars represent the dry season, dark bars the rainy season (for statistics see 'Results'). Numbers in brackets beside months indicate total number of samples collected per month
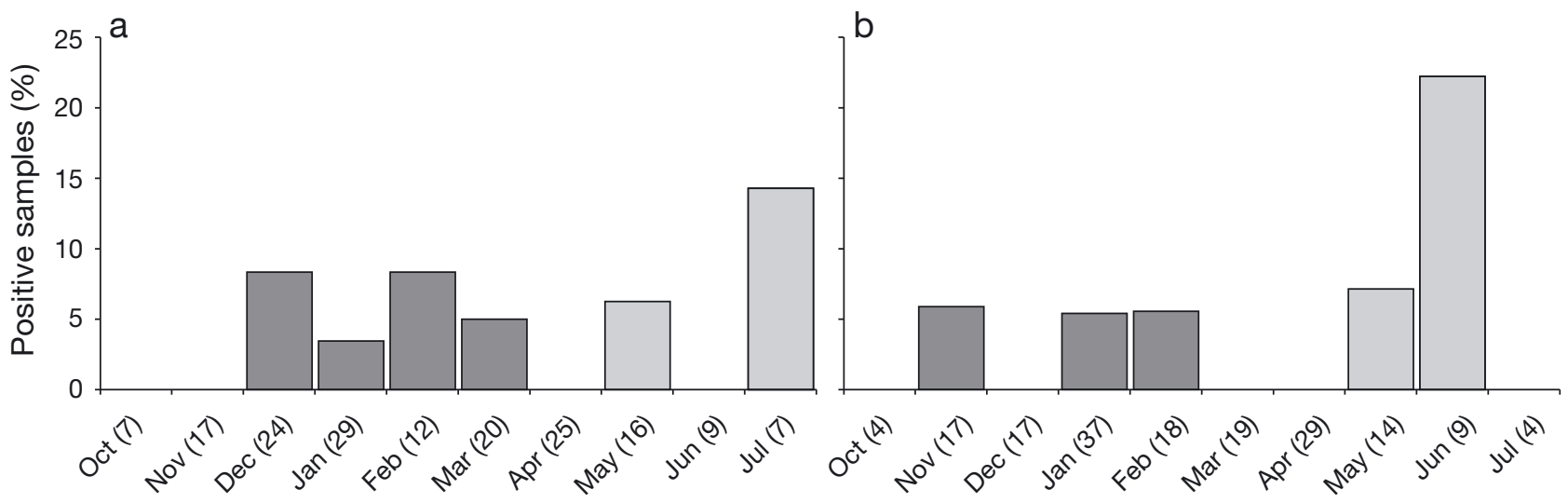

Fig. 7. Eulemur flavifrons. Shedding of Callistoura sp. eggs by lemurs in (a) primary and (b) secondary forest. Light bars represent the dry season, dark bars the rainy season (Extension Fisher test, primary vs. secondary forest: $\mathrm{n}=334 ; \mathrm{p}>0.1$ ). Numbers in brackets beside months indicate total number of samples collected per month 


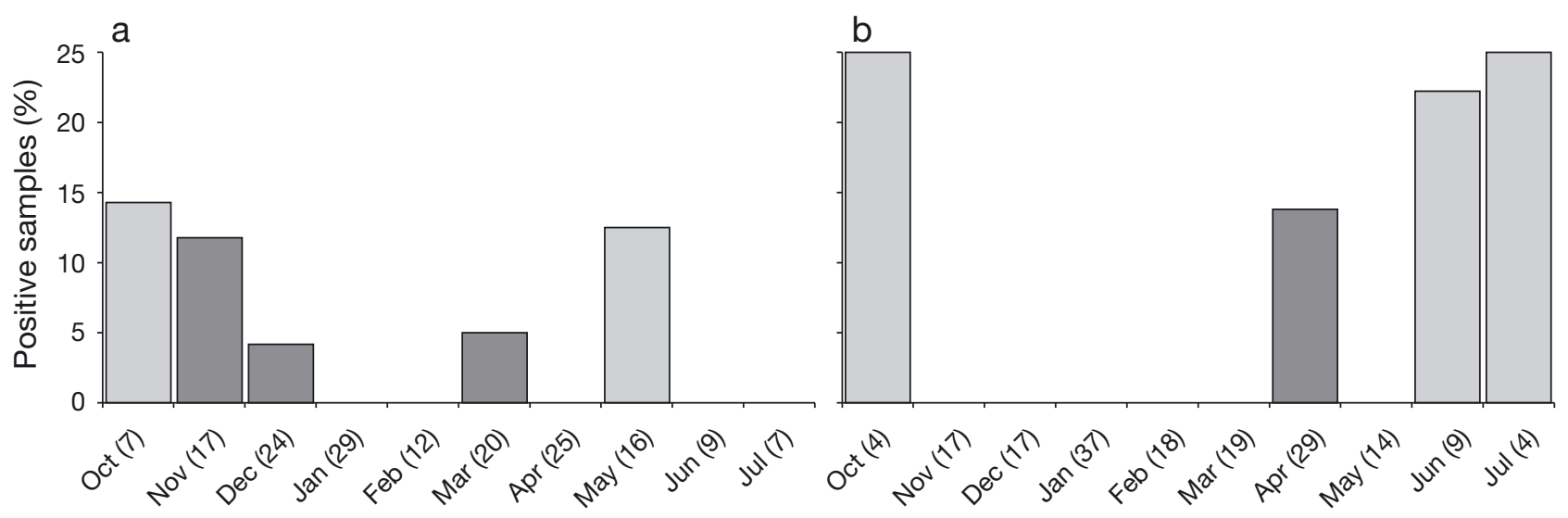

Fig. 8. Eulemur flavifrons. Shedding of Lemuricola sp. eggs by lemurs in (a) primary and (b) secondary forest. Light bars represent the dry season, dark bars the rainy season (Extension Fisher test, primary vs. secondary forest: $\mathrm{n}=334 ; \mathrm{p}>0.1$ ). Numbers in brackets beside months indicate total number of samples collected per month
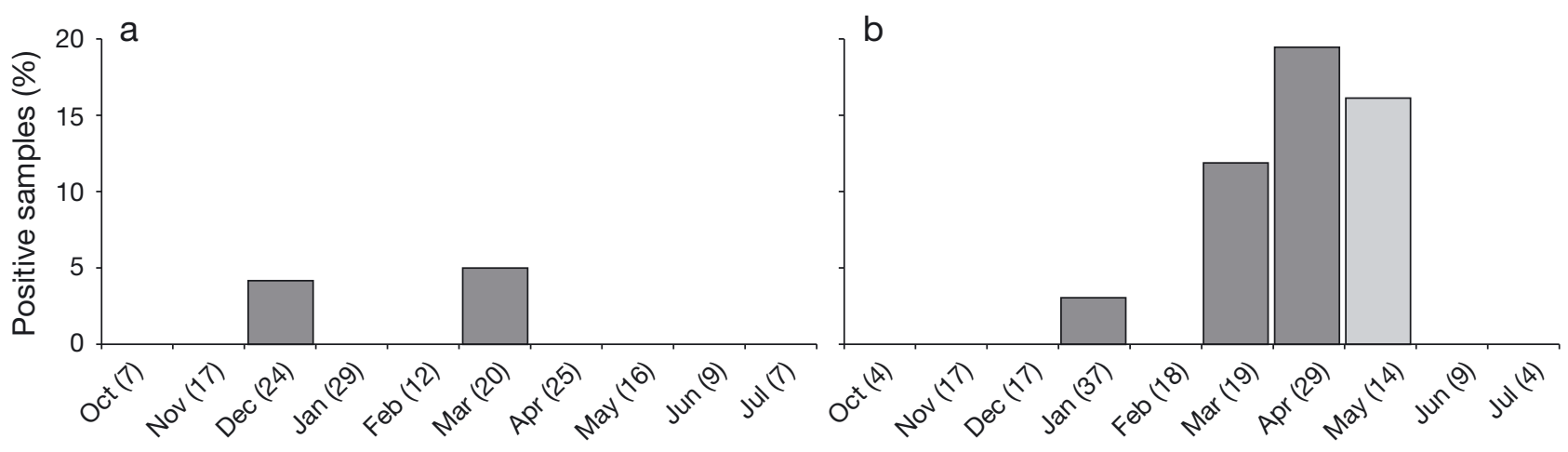

Fig. 9. Eulemur flavifrons. Shedding of oocysts by lemurs in (a) primary and (b) secondary forest. Light bars represent the dry season, dark bars represent the rainy season (Extension Fisher test, primary vs. secondary forest: $n=334 ; p>0.1$ ). Numbers in brackets beside months indicate total number of samples collected per month

were positive for parasite eggs, oocysts or larvae. Of the samples from the immobilised blue-eyed black lemurs, $55.6 \%$ contained adult parasites. Prevalence in our sample was high when compared to samples of immobilised wild ruffed lemurs $(11.1 \%, \mathrm{n}=9$, Junge \& Louis 2005a; $11 \%, \mathrm{n}=18$, Dutton et al. 2008), red-fronted lemurs $(30 \%, \mathrm{n}=10$, Junge \& Louis 2005b), Von der Decken's sifakas ( $45 \%, \mathrm{n}=11$, Junge \& Louis 2005b), black lemurs $(40 \%, \mathrm{n}=10$, Junge \& Louis 2007) and ring-tailed lemurs (30\%, Dutton et al. 2003). Junge et al. (2008) found a comparably high prevalence of enteric parasites $(62 \%, \mathrm{n}=29)$ in their sample of immobilised wild white-fronted lemurs from 4 different study sites. However, of these 4 sites, the one with the highest prevalence $(100 \%, \mathrm{n}=10)$ was Nosy Mangabe, a small island in the Antongil Bay covered by regenerated lowland rain forest and harbouring an unusually high density of diurnal lemurs. Without the animals from Nosy Mangabe, total prevalence in Junge et al.'s (2008) study would have been $42 \%(n=19)$.
Junge \& Louis (2007) and Junge et al. (2008) suggested that the level of parasitism found in their studies was likely to reflect a commensal relationship and was not of clinical significance (see also Junge \& Sauther 2006). Whether the parasites found in our study are pathogens remains unknown, but the animals did not show any obvious clinical signs of disease (e.g. diarrhoea, mucus or blood in faeces, emaciation).

Junge \& Louis (2007) further suggested that changes in incidence and prevalence of parasites in lemurs may be an indicator of stress caused by the presence of humans or domestic animals (but not due to direct transmission from humans or commensals). Our data suggest that Eulemur flavifrons were generally under stress, possibly due to the extremely high degree of fragmentation and degradation of their habitat, which may have led to a higher parasite burden than lemurs would normally carry in more undisturbed habitats. Almost $13 \%$ of all samples contained parasite eggs of 
either Callistoura sp. or Lemuricola sp., or oocysts. The absence of other intestinal protozoa in blue-eyed black lemurs in the wild is remarkable, especially since the parasite diversity in other wild lemur populations was shown to be higher (e.g. Raharivololona \& Ganzhorn 2009, 2010).

The primary forest fragment in Ankarafa was less disturbed, harboured more large food trees and offered more potential sleeping and resting trees than the secondary forest fragment (Schwitzer et al. 2007a). The effect of the lower density of food resources and resting trees as well as larger home ranges (Schwitzer et al. 2007a) and thus a higher potential of stress for blue-eyed black lemurs in secondary forest might have led to a significantly higher parasite burden in this habitat type.

However, the number of recently cut trees was higher in the primary forest fragment due to recent human activity, and the lemurs were also more often spotted on the ground (Schwitzer et al. 2007a). Gillespie \& Chapman (2006) found a strong relationship between tree stump density and parasite burden in red colobus monkeys Piliocolobus tephrosceles. They suggested that monkeys inhabiting fragments with high stump density were likely to experience a higher probability of human contact (novel pathogens, chronic stress), reduced food availability, and restricted ranging (more intensive use of fewer arboreal pathways, more frequent use of the ground), any or all of which may have led to a high parasite prevalence. Parallel investigations in previously selectively logged forest that had been placed under protection from use by the time of the study suggested that human contact may play a more important role in predicting parasite prevalence than reduced food availability (Gillespie et al. 2005). These relationships were not observed in blue-eyed black lemurs in the present study, but may have been masked by the extreme degree of fragmentation of the Ankarafa Forest and the resulting overall high parasite burden of the lemurs studied.

Seasonality in parasite prevalence is often linked to a relatively short life of the parasites. It is often regulated by climate, which again affects the parasites' reproductive cycles (Taraschewski 2006). In our study, prevalence in general was higher during the warm wet season, suggesting a short life for Callistoura sp. or Lemuricola sp. However, these results need to be interpreted with caution, since the samples for the different parasites were small, and sampling bias may have had a confounding effect.

Mites were found on the inner side of the ears of a third of all immobilised individuals. They are possibly from the family Laelapidae, which is commonly found on several lemur species at multiple sites (Junge et al. 2008). The mites did not seem to be associated with clinical disease.
None of the sampled lemurs was infected with a zoonotic parasite. Ashford et al. (1990) and Hahn et al. (2003) reported a lack of Ascaris infection in gorillas Gorilla gorilla beringei and baboons Papio cynocephalus and $P$. anubis compared with humans in the same region. The actual parasitic burden of the human population in Sahamalaza at the time of sample collection is unknown, as for cultural reasons it was not possible to collect faeces samples from the surrounding villages. However, 3 field assistants were detected to be positive for gastrointestinal parasites. The assumption that the study groups in secondary forest are more likely to be exposed to the infectious stages of human parasites is based on people frequently crossing the secondary forest fragment on their way between villages and locals harvesting Ravenala for their traditional buildings in this area.

Our findings provide evidence that a recently selectively logged primary forest differs significantly from a $35 \mathrm{yr}$ old secondary forest in terms of the parasite prevalence of its blue-eyed black lemur inhabitants. Although recently started and ongoing human exploitation of otherwise intact forest fragments may be a factor affecting disease burden and parasite transmission (Gillespie \& Chapman 2006), which clearly shows in an overall high parasite burden of blue-eyed black lemurs in this study in both habitat types, the secondary forest fragment nevertheless seems to put the lemurs under more stress and thus seems less suitable for Eulemur flavifrons over the long term (see also Schwitzer et al. 2007a,b).

\section{CONCLUSIONS}

The overall high parasite load of Eulemur flavifrons compared to other lemur species in different areas of Madagascar suggests that the study populations are generally under stress, possibly because of the extremely high degree of fragmentation and degradation of their habitat in Sahamalaza National Park.

Blue-eyed black lemurs in a 35 yr old secondary forest fragment had a significantly higher parasite load than those in a recently disturbed primary forest fragment, indicating that isolated secondary forest may not provide a suitable long-term habitat.

Further studies are necessary to investigate whether the high parasite prevalence found in Eulemur flavifrons in fragmented and degraded habitat is determined by ecological factors associated with fragment size and degradation only, or whether possible low genetic diversity may also play a role. The latter may favour the accumulation of certain alleles of the major histocompatibility complex that are associated with a higher susceptibility to parasite infection (Schad et al. 2005). 
Acknowledgements. We thank the Ministère de l'Environnement, des Forêts et du Tourisme and Madagascar National Parks (formerly ANGAP) for granting a research permit, as well as C. Rabarivola from the University of Mahajanga and G. Nogge from Cologne Zoo for their assistance. We also thank I. Massman and D. White, as well as our field assistants Y.C. Jaomamory, A. 'Richard' Randrianasara, J. C. 'Zafihita' Milson and T. Jean-Ede, who all contributed essential support. Comments from 3 anonymous reviewers considerably improved the manuscript. This study was supported by the Association Européenne pour l'Etude et la Conservation des Lémuriens (AEECL), the Margot Marsh Biodiversity Foundation and the Conservation International Primate Action Fund. Equipment was sponsored by Thrane\&Thrane (Lyngby, Denmark), ESRI ArcView9.1 Student Edition and Bushnell (Cologne, Germany).

\section{LITERATURE CITED}

Ash LR, Orihel TC (1987) Parasites: a guide to laboratory procedures and identification. American Society of Clinical Pathologists Press, Chicago, IL

Ashford RW, Reid GDF, Butynski TM (1990) The intestinal faunas of man and mountain gorillas in a shared habitat. Ann Trop Med Parasitol 84:337-340

Chabaud AG, Brygoo ER, Petter AJ (1965) Parasitic nematodes of Malagasy lemurs. VI. Description of six new species and general conclusions. Ann Parasitol Hum Comp 40:181-214

Chokkalingam U, de Jong W (2001) Secondary forest: a working definition and typology. Int For Rev 3:19-26

Daszak P, Cunningham AA, Hyatt AD (2000) Emerging infectious diseases of wildlife - threats to biodiversity and human health. Science 287:443-449

Dobson AP (1988) The population biology of parasite-induced changes in host behavior. Q Rev Biol 63:139-165

Dutton CJ, Junge RE, Louis EE (2003) Biomedical evaluation of free-ranging ring-tailed lemurs (Lemur catta) in Tsimanampetsotsa Strict Nature Reserve, Madagascar. J Zoo Wildl Med 34:16-24

Dutton CJ, Junge RE, Louis EE (2008) Biomedical evaluation of free-ranging red ruffed lemurs (Varecia rubra) within the Masoala National Park, Madagascar. J Zoo Wildl Med 39:76-85

Foose TJ (1991) Viable population strategies for re-introduction programmes. Zool Soc Lond Symp 62. Zoological Society of London, London

Garnham PCC, Uilenberg G (1975) Malaria parasites of lemurs. Ann Parasitol Hum Comp 50:409-418

Gillespie TR, Chapman CA (2004) Forest fragmentation alters primate parasite dynamics: implications for primate health and conservation. Folia Primatol 75(Suppl 1):267

Gillespie TR, Chapman CA (2006) Prediction of parasite infection dynamics in primate metapopulations based on attributes of forest fragmentation. Conserv Biol 20: 441-448

Gillespie TR, Chapman CA, Greiner EC (2005) Effects of logging on gastrointestinal parasite infections and infection risk in African primates. J Appl Ecol 42:699-707

Graczyk TK, da Silva AJ, Cranfield MR, Nizeyi JB, Kalema G, Pieniazek NJ (2001) Cryptosporidium parvum genotype 2 infections in free-ranging mountain gorillas (Gorilla gorilla beringei) of the Bwindi Impenetrable National Park, Uganda. Parasitol Res 87:368-370

> Hahn NE, Proulux D, Muruthi PM, Alberts S, Altmann J (2003) Gastrointestinal parasites in free-ranging Kenyan baboons (Papio cynocephalus and P. anubis). Int J Primatol 24:271-279

Huff CG, Hoogstraal H (1962) Plasmodium lemuris n. sp., from Lemur collaris E. Geoffroy. J Infect Dis 112:233-236 > Hugot JP, Morand S, Gardner SL (1995) Morphology and morphometrics of three oxyurids parasitic in primates with a description of Lemuricola microcebi n. sp. Int J Parasitol 25:1065-1075

IRNT (Inventaire des Ressources Naturelles Terrestres de Madagasikara) (1991a) Carte des ressources en sols. Feuille SC 38:L FTM, Antananarivo

IRNT (1991b) Carte des ressources en eaux. Feuille SC 38:L FTM, Antananarivo

Junge RE, Louis EE (2005a) Biomedical evaluation of wild ruffed lemurs (Varecia variegata and V. rubra). Am J Primatol 66:85-94

Junge RE, Louis EE (2005b) Biomedical evaluation of two sympatric lemur species (Propithecus verreauxi deckeni and Eulemur fulvus rufus) in Tsiombokibo classified forest, Madagascar. J Zoo Wildl Med 36:581-589

Junge RE, Louis EE (2007) Biomedical evaluation of black lemurs (Eulemur macaco macaco) in Lokobe Reserve, Madagascar. J Zoo Wildl Med 38:67-76

Junge RE, Sauther ML (2006) Overview on the health and disease ecology of wild lemurs: conservation implications. In: Gould L and Sauther ML (eds) Lemurs: ecology and adaptation. Springer, New York, NY, p 423-440

Junge RE, Dutton CJ, Knightly F, Williams CV, Rasambainarivo FT, Louis EE (2008) Comparison of biomedical evaluation for white-fronted brown lemurs (Eulemur fulvus albifrons) from four sites in Madagascar. J Zoo Wildl Med 39: $567-575$

Karesh WB, Cook RA (1995) Applications of veterinary medicine to in situ conservation efforts. Oryx 29:244-252

Koenders L, Rumpler Y, Ratsirarson J, Peyrieras A (1985) Lemur macaco flavifrons (Gray, 1867): a rediscovered subspecies of primates. Folia Primatol 44:210-215

Krantz GW (1978) A manual of acarology. 2nd edn. Oregon State University Book Store, Corvallis, OR

May B, Moody DB, Stebbins WC (1988) The significant features of Japanese macaque coo sounds: a psychophysical study. Anim Behav 36:1432-1444

Mehlhorn H, Eichenlaub D, Löscher T, Peters W (1995) Diagnostik und Therapie der Parasitosen des Menschen. Gustav Fischer Verlag, Stuttgart

Meier B, Lonina A, Hahn T (1996) Expeditionsbericht Sommer 1995 - Schaffung eines neuen Nationalparks in Madagaskar. Z Köln Zoo 39:61-72

Meyers DM, Rabarivola C, Rumpler Y (1989) Distribution and conservation of Sclater's lemur: implications of a morphological cline. Primate Conserv 10:77-81

Mittermeier RA, Tattersall I, Konstant WR, Meyers DM, Mast RB (1994) Lemurs of Madagascar. Conservation International Tropical Field Guide Series. Conservation International, Washington, DC

Mittermeier RA, Ganzhorn JU, Konstant WR, Glander K and others (2008) Lemur diversity in Madagascar. Int J Primatol 29:1607-1656

Mörner T (2002) Health monitoring and conservation of wildlife in Sweden and northern Europe. Ann NY Acad Sci 969:34-38

Mouton E (1999) Mission de terrain sur la presqu'île de Sahamalaza (Nord-ouest Madagascar). Rapport préliminaire pour la création d'une aire protégée. Zoo de Mulhouse, Mulhouse

Nizeyi JB, Mwebe R, Nanteza A, Cranfield MR, Kalema GR, Graczyk TK (1999) Cryptosporidium sp. and Giardia sp. 
infections in mountain gorillas (Gorilla gorilla beringei) of the Bwindi Impenetrable National Park, Uganda. J Parasitol 85:1084-1088

Nizeyi JB, Cranfield MR, Graczyk TK (2002a) Cattle near the Bwindi Impenetrable National Park, Uganda, as a reservoir of Cryptosporidium parvum and Giardia duodenalis for local community and free-ranging gorillas. Parasitol Res 88:380-385

Nizeyi JB, Sebunya D, da Silva AJ, Cranfield MR, Pieniazek NJ, Graczyk TK (2002b) Cryptosporidiosis in people sharing habitats with free-ranging mountain gorillas (Gorilla gorilla beringei), Uganda. Am J Trop Med Hyg 66: 442-444

Pastorini J (2000) Molecular systematics of lemurs. PhD dissertation, Universität Zürich

Rabarivola C (1998) Etude génétique comparative de populations insulaires et 'continentales' de Eulemur macaco. Utilisation simultanée des dermatoglyphes, de marqueurs sanguins et de l'ADN (RAPD) pour étudier la différenciation de E. macaco en deux sous-espèces: E. m. macaco et E. m. flavifrons. PhD dissertation, Université d'Antananarivo

Rabarivola C, Meyers D, Rumpler Y (1991) Distribution and morphological characters of intermediate forms between the black lemur (Eulemur macaco macaco) and Sclater's lemur (Eulemur macaco flavifrons). Primates 32:269-273

Rabetafika L, Landau I, Baccam D, Lepers JP, Coulanges P, Rakotofiringa S (1989) Sporogony and pre-erythrocytic schizogony of Plasmodia from lemurs of Madagascar. Ann Parasitol Hum Comp 64:243-250

Raharivololona BM, Ganzhorn JU (2009) Gastrointestinal parasite infection of the gray mouse lemur (Microcebus murinus) in the littoral forest of Mandena, Madagascar: effects of forest fragmentation and degradation. Madag Conserv Dev 4:103-112

Raharivololona BM, Ganzhorn JU (2010) Seasonal variations in gastrointestinal parasites excreted by the gray mouse lemur Microcebus murinus in Madagascar. Endang Species Res 11:113-122

Schad J, Ganzhorn JU, Sommer S (2005) Parasite burden and constitution of major histocompatibility complex in the Malagasy mouse lemur, Microcebus murinus. Evolution 59:439-450

Schwitzer C, Schwitzer N, Randriatahina GH, Rabarivola C, Kaumanns W (2005) Inventory of the Eulemur macaco flavifrons population in the Sahamalaza protected area,

Editorial responsibility: Anna Nekaris,

Oxford, UK northwestern Madagascar, with notes on an unusual colour variant of E. macaco. Primate Rep Spec Iss 72: 39-40 (Abstract)

Schwitzer C, Schwitzer N, Randriatahina GH, Rabarivola C, Kaumanns W (2006) 'Programme Sahamalaza': new perspectives for the in situ and ex situ study and conservation of the blue-eyed black lemur (Eulemur macaco flavifrons) in a fragmented habitat. In: Schwitzer C, Brandt S, Ramilijaona O, Rakotomalala Razanahoera M, Ackermand D, Razakamanana T, Ganzhorn JU (eds) Proc German-Malagasy Research Cooperation in Life and Earth Sciences. Concept Verlag, Berlin, p 135-149

> Schwitzer N, Randriatahina GH, Kaumanns W, Hoffmeister D, Schwitzer C (2007a) Habitat utilization of blue-eyed black lemurs, Eulemur macaco flavifrons (Gray, 1867), in primary and altered forest fragments. Primate Conserv 22: 79-87

> Schwitzer N, Kaumanns W, Seitz PC, Schwitzer C (2007b) Cathemeral activity patterns of the blue-eyed black lemur Eulemur macaco flavifrons in intact and degraded forest fragments. Endang Species Res 3:239-247

Spalding MG, Forrester DJ (1993) Pathogenesis of Eustrongylides ignotus (Nematoda: Dioctophymatoidea) in Ciconiiformes. J Wildl Dis 29:250-260

Stuart M, Pendergast V, Rumfelt S, Pierberg S, Greenspan L, Glander K, Clarke M (1998) Parasites of wild howlers (Alouatta spp.). Int J Primatol 19:493-512

Taraschewski H (2006) Parasiten und Wirte als Bestandteile von Ökosystemen. In: Hiepe T, Lucius R, Gottstein B (eds) Allgemeine Parasitologie mit den Grundzügen der Immunologie, Diagnostik und Bekämpfung. Parey, Stuttgart, p 276-325

WCS/DEC (Wildlife Conservation Society/Development Environment Consult) (2002) Etude de faisabilité de la création d'APMC et plan de développement pour le site de la RBM Sahamalaza-Nosy Radama. WCS/DEC, Antananarivo

> Thorne ET, Williams ES, Spraker TR, Helms W, Segerstrom T (1988) Bluetongue in free-ranging pronghorn antelope (Antilocapra americana) in Wyoming: 1976 and 1984. J Wildl Dis 24:113-119

Williams CV, van Steenhouse JL, Bradley JM, Hancock SI, Hegarty BC, Breitschwerdt EB (2002) Naturally occurring Ehrlichia chaffeensis infection in two prosimian primate species: ring-tailed lemurs (Lemur catta) and ruffed lemurs (Varecia variegata). Emerg Infect Dis 8:1497-1500

Submitted: January 30, 2009; Accepted: July 5, 2010

Proofs received from author(s): September 3, 2010 